\title{
To Dance the Native Dance: Vernacular Modernism in an "Australian-New Zealand Comedy Romance"
}

\author{
MINETTE HILLYER
}

\begin{abstract}
This article studies The Adventures of Algy, a 1925 "Australian-New Zealand comedy-romance," and in particular the "Māori dance" performances of its Pākeha heroine, Kiwi McGill. Dance serves multiple functions in the film, reflecting a trend for primitivism in global silent cinema, claiming Māori performance culture for a settler colonial narrative, and acting as a means to translate modern experiences. As such it offers a mechanism to reconsider what Miriam Hansen has described, in relation to the classical Hollywood cinema, as "vernacular modernism" in the form of a minor, and only marginally successful film: "one of ours."
\end{abstract}

The Adventures of Algy (1925) — “a novel Australian-New Zealand comedy-romance" — is a rare example of a feature film from New Zealand's silent period set in its present day. ${ }^{1}$ While its Australian producer-director Beaumont Smith promised "an epic ... unsurpassed in spectacle since The Birth of a Nation!," what he delivered was much less distinguished. ${ }^{2}$ Algy romps between locations, plot points, and amusing spectacles, its effort to provide a recognizably entertaining product to that prosaic group of people who sought to be entertained. It is opportunistic, eclectic in its plot and genre references, and apparently designed to turn a profit. ${ }^{3}$ Jonathan Dennis, the founding director of New Zealand's national film archive, later described it with great affection as "Not a Napoleon, a Broken Blossoms, or a Sunrise - something just as special, but altogether rarer: one of ours...."4

What is it then, to be that rare thing, one of ours? Other works of New Zealand's silent cinema are better known, and have a more storied genealogy, but what Algy lacks in artistry, Dennis implies, it makes up for with being idiomatic, local, vernacular. While it is not formally innovative, it is modernist in the terms that Marshall Berman provides, as it speaks to the effort by its makers to "become subjects as well as objects of modernization, to get a grip on the modern world and make themselves at home in it."

Its story is, moreover, about making a home. Claude Dampier, an English music hall entertainer known to local audiences, plays Algy, a "silly ass" character who comes to New Zealand from London, (complete with monocle, and clutching a crossword puzzle), to claim the land left him by an uncle (a farm and some unexploited territory). There, he falls in love with the "fascinating" Kiwi McGill, a Pākehā and the daughter of the farm manager. Thwarted by a combination of social awkwardness, Kiwi's exceptional self-containment, and a lack of opportunity to stake his claim, Algy wanders the country with his crossword while Kiwi leaps at an offer to go to Sydney to appear in a theatrical revue built around her "Maori dancing." After a few plot twists and turnslargely involving Algy's dastardly cousin Murray, who is in competition with him both for the land and for the hand of the "fascinating" Kiwi - the resolution of Algy's torment in the final kiss is achieved only after Kiwi dons her costume and dances again.

If Algy represents an effort to be at home in modernity, it does so with recourse to a popular symbol of the premodern: "the native dance." "To dance the native dance" is presented in the film as Kiwi McGill's particular talent, a rare skill which identifies her-like the film — as a "novelty,"

Journal of New Zealand Studies NS25 (2017), 40-56 
and as "one of ours." My use of the phrase here is opportunistic and extratextual, as Algy itself is. It was used in a Chicago newspaper to describe the actress who played Kiwi McGill five years after the film's making as "the unofficial ambassador from New Zealand... the only white woman who can dance the native dance." It implies a facility with culture, extending beyond the dance itself to imply that the "dancer" knows how to operate, that they are at home in their culture. It is also a clear appropriation of indigenous cultural performance, separating dance from dancer and reunifying them in the person of the settler-indigene. The "native dance" is then a metaphor: for indigeneity, and for the settler's will to indigenize. ${ }^{7}$

Dance was a prominent, regular feature of New Zealand's silent period feature films. Their distinction in the global cinema circuit was to offer a variation on popular themes in which the spectacle of indigeneity variously acted as an alternative to "a botched civilization," or a titillating spectacle of savagery. ${ }^{8}$ Kiwi's dance, however, offers something else again: it is ance a claim to indigeneity, an expression of soft primitivism, a reference to other works of popular cinema, an individuating narrative device, and an assertively modern spectacle. As her dance features in the film - at home, in tourist sites, and on the metropolitan stage - it serves a local, and putatively national culture, and claims a place for that culture in a modern circuit of exchange. The dance is itself at once emphatically local—both "native," and occurring in local space_-and demonstrably part of a global machinery of modern entertainment. Dance thus acts as a translating force: as the film's clearest and most problematic assertion of local distinctiveness, and as a conjunctive to a more global culture of modernity.

In what follows, I wish to pursue this question of how the modern and the local converge in Algy's story of "the native dance." My narrative takes three parts, headlined with declamations, each an intertitle from the film, following the movements of dance's mediating role. In the first, indigenous dance functions as modern entertainment; in the second, as evidence of the settlercolonial appropriation of indigenous culture; and in the third, as a means of registering and reflecting modern spaces and worldviews. In organizing my story in this way, I hope to reflect on Algy's own narrative style, which is not always graceful but consistently declamatory. In its explicit, sometimes ungainly citations of modern texts and experiences, Algy is stitched into its productive community and self-reflexive in its engagement with modern life. In its efforts to be adequate to its modern technology (the movies), its modern locale, and the modern experiences of those represented by it, the film also suggests its public's familiarity with the narrative tropes and spaces of modernity. In these ways, it points toward Miriam Hansen's discussion of vernacular modernism, in which she claims that cinema acts as a privileged forum to "register, respond to, and reflect upon processes of modernization and the experience of modernity." "Some of what New Zealand audiences knew of modernity came to them by way of the movies, which were hugely popular and culturally influential, as well as generally foreign in origin. The Adventures of Algy, however-like other works of "small-nation cinemas"-offers a means to think about the issues of cultural translation which Hansen's argument raise not in the reception of an imported film, but in the production of "one of ours."10

What is produced here is not just a film, but a vision - or version - of modern cultural experience. That is, the film offers a minor case study of the widely accepted idea that modernity is experienced as locally variable in space and time. Its "production of locality," as Arjun Appadurai writes - its "local teleology and ethos"-is shaped precisely by this truth. ${ }^{11}$ Algy reflects the desire to be modern, the conviction that movies definitively are so, and the knowledge of what a local experience of modernity looks like. It can be seen as purposive in its efforts not

Journal of New Zealand Studies NS25 (2017), 40-56 
only, as Hansen writes of cinema in general, to "register, respond to, and reflect upon ... the experience of modernity," but to assert a narrative of modernity particular to its place. Most significantly, Algy's local teleology and ethos reflect the imperatives of a settler colonial society, in which settlement is itself assertive, and placed under advisement by the persistence of the indigenous people; in which the story of modernity must take into account the actual presence of Māori, even as local cinema audiences are repeatedly exposed to the idea that indigeneity - the "native"-functioned as a structuring historical backdrop to modern life: elsewhere and in another time.

Other studies have pursued the question of the "politics of space" in silent cinema much more rigorously than I can here. ${ }^{12}$ However, it is striking, when considering Algy as "one [a movie] of ours [not theirs]" how much it seems at once to strive to be 'as modern' as Hollywood, and to purposively fall behind; how much it seems to speak a language in translation, and in the vernacular; how its particular efforts to be modern are made up of a series of impersonations of imported movies and movie 'types', local productions and performances, national aspirations, and native resources. In short, Algy's modern compass points are eclectic, and its relationship to the story of modernity messy, and idiomatic. The same may be said of its "native dance."

\section{"Dance For Us ... and Forget Your Troubles."}

The dance scenes in The Adventures of Algy are at once pivotal, and incidental to a crowded narrative: a prominent Australian entertainment magazine's review of the film included them in the category of "padding" to a "slight plot." 13 Padding they might be, but they serve the purpose of making the film recognizable, offering a reliable opportunity to entertain. Dance, broadly defined, featured regularly in the lexicon of New Zealand's silent period film, beginning with the first film commissioned by the New Zealand government, Royal Visit of the Duke and Duchess of Cornwall and York to New Zealand, $1901 .{ }^{14}$ Until the early 1920s, state-sponsored films such as this one tended to be opportunistic, motivated by "great events"; such events increasingly incorporated aspects of Māori performance culture, as reflected in this first film. ${ }^{15}$ Likewise, many films featured views of Whakarewarewa, which would become "most filmed location in New Zealand," and is the implied location for Kiwi McGill's first public dance performance in The Adventures of Algy. ${ }^{16}$ By staging her first public dance there, the film refers both to a local history of performance and to a developing screen tradition, using the "native dance" as a bridging technology for performances of a vernacular modernity.

Kiwi's dance at Whakarewarewa occurs at the invitation of Mary, "[h]er [Māori] friend with that big simple heart." Having changed into Māori costume for her visit, Kiwi sits with the residents of the model village and relates her all-too familiar dilemma. Her father's fortunes are in ruin; they stand to lose their home unless she gives herself to Murray, Algy's mustachioed cousin, who has taken over the farm. "Dance for us, Kiwi" Mary suggests, "and forget your troubles." Her initial reticence quickly overcome, Kiwi springs to her feet and is swept up in her dance, to the extent that she fails to notice the arrival of a small party of visitors accompanied by a guide. Kiwi, gazing skyward, seems to both harmonise with and stand apart from her Māori companions, who remain seated. Her idyll is only interrupted by an offer of work, based on a visitor's apprehension of her unique qualities: "He was producing a new revue in Sydney and here was a distinct novelty for it." It is an offer to which her friends give their tacit assent. Kiwi, released from her troubles after all, runs down the road, encountering a befuddled Murray on her way. 
Films like The Adventures of Algy - which were not designed to commemorate but to divert-recalled their state-sponsored counterparts by habitually featuring Māori dance performance, often in close proximity to geysers and mud pools, with varying degrees of cultural, genealogical, and geographical verisimilitude. Their use of dance reflects their integration in a global cinema circuit founded on spectacle from the outset. New Zealand was a destination for metropolitan filmmakers starting in 1912 when Gaston Méliès' embarked for the "South Seas," seeking "novel" subjects for audiences already fatigued by the Western. ${ }^{17}$ According to Emile de Brigard, the most successful was shot in New Zealand: Loved By A Maori Chieftess. "The action," he wrote, "took place against a background of genuine village life, dancing, and war canoes."18 While many films made in New Zealand in the silent period are lost, it is safe to assume that a large number featured Māori dancing in some form, with cultural performance serving as evidence of a picture's appeal and distinction. Under the Southern Cross (1929), for instance, was described in a local review as featuring "mass movements of the tribes, a fascinating sort of hurdle contest, rhythmic and often very phallic dances," while Gustav Pauli's The Romance of Hinemoa (1927), shot in Rotorua, was preceded in its first screenings in Christchurch by a Māori performance troupe who would, the local paper noted, "appear in poi dances, canoe dances, and hakas, and ... sing the weird and enchanting songs of their race in their own unique way." 19 More than a reflection of their fidelity to actual cultural practices, in these commentaries we see the affective charge of primitivism, the persistence of the exotic and wondrous, and the force of cinematic spectacle, even when that spectacle is generated quite close to home.

The pleasures of spectacle notwithstanding, authenticity remained a significant value. In narrative films from this period, dance often appears in quasi-ethnographic interludes in which an avowedly traditional romance is laced with evidence of Māori material and performance culture. Haka and poi sit alongside the preparation of meals, the weaving of baskets and cloaks, practise with taiaha and images of Māori in situ, just as Kiwi's Māori friends sit by her side in the model village. Visual tableaux like these testify to the versimilitude of the cinematic image and the authenticity of its narrative: the first because they offer indexical proof of "the native," and the second because they place the film's narrative in light of the ethnographic. ${ }^{20}$ The romance stakes its claim on the "universal," the ethnographic detail on the local and particular. Publicity material for films featuring Māori accordingly emphasises their authenticity: George Tarr's 1914 film Hinemoa, for example, was described as "the first picture on record which has been acted entirely by natives," and as "Filmed in Rotorua! On the original spots which have been handed down by generations of Maoris as authentic landmarks in the lives of their ancestors." 21 The advertisement's claim to authenticity via its cast of "natives" recalls their apparently inherent exoticism (Māori are authentically "other"), while its possessive citation of geography - or even genealogy-via historically "authentic landmarks" suggests a more modern, ethnographic perspective, emphasising a knowledge of lived culture and its potential for taxonomic classification (Māori are authentically "cultural").

The conjuncture of these two perspectives (one exotic / evolutionary, one classificatory / ethnographic) indicates larger forces shaping the perception of cultural difference in film's silent period, and thus of a way of being modern which was reconciled with the primitive. The first decades of the twentieth century saw major changes in the production of knowledge of culture: a move from museum-based anthropologists to ethnographers in the "field"; from the local, amateur authority of the traveller or missionary to the more expert claims of the trained social scientist; and from an evolutionary to an ethnographic model of anthropology. James Clifford has described the

Journal of New Zealand Studies NS25 (2017), 40-56 
"formation ... of ethnographic authority," an authority "both scientifically validated, and based on a unique personal experience" as a feature of the period. ${ }^{22}$ The effects of this emerging episteme are visible across the field of modern cultural production and display. Thus, Conal McCarthy describes the exhibition of Māori material culture in New Zealand museums from the latenineteenth century to the $1920 \mathrm{~s}$ in terms of a definitional shift from curio (defined by its strangeness), to ethnological specimen (defined by its representativeness of a people, or race), to artifact (defined by its representativeness of culture). ${ }^{23}$ The ethnological turn is perhaps played out even more persistently in popular cinema, reflecting a tendency to borrow without clear citation as well as its particular abilities to simulate "unique personal experience," and to validate that experience by providing visual truth and spectacle all at once. The conjuncture of the exotic and the evidentiary thus finds its median in cinema. As Fatimah Tobing Rony writes, "[1]ike ethnography, cinema is ... a topos for the meeting of science and fantasy." 24 The "native romance" is defined as such not only because it presents a love story, but because it is "romantic"-defined by its "remoteness from everyday life"-with cultural display acting as a proof of contact, and as a portal to an imagined primitive past. ${ }^{25}$ Films made in a variety of "exotic" locations in the teens and twenties mined a rich seam of primitivist spectacle as a means of offering evidently authentic cultural experiences to jaded metropolitan audiences, with direct consequences for their success, particularly as the degree to which they were "ethnological" determined whether the most spectacular displays - of breasts and buttocks, for example — would be excused in the name of cultural inquiry. ${ }^{26}$

In general, in the feature films made in New Zealand, dance provides a spectacular addition (or interruption) to the narrative, based as much on iterations of primitivist spectacle found elsewhere in popular culture as actual tikanga Māori. ${ }^{27}$ However, in a film that is determined to be both modern and idiomatic, as Algy is, the customary markers of this spectacle are reformed. In comparison with many cinematic displays of "native dance" Kiwi's dance is chaste, despite establishing her as an object of curiosity and of desire. Her first dance performance occurs one evening before her appearance at the model village, when she gives a sitting room "exhibition of Poi-dancing" for Murray and Algy — her guests, and the heirs to her home. She is dressed in full costume: piupiu; a woven bodice; a headband; and of course, her poi. Algy joins in, an awkward participant in the dance, but Murray-whose desire for Kiwi has been evident since her first appearance in the film-remains a fascinated observer. He stalks her from behind, clasping her feverishly from the rear as she carries on gamely with her demonstrating. The performance at home places Kiwi's dance explicitly into the domestic realm, while framing her as a cultural indigene. In this she embodies the "unique personal experience" that Clifford describes as underlying an ethnographic command of culture. Her dance is, in fact, quite unique: "native" in name and generally in costume, but indebted to a romantic vision of modern femininity that distinguishes her performance from actual Māori performance. Kiwi always wears heeled shoes; her gaze is perpetually skywards, rather than engaged with her actions; her stance is coy; and her movements - while often charged with vivacity — lack the precision of poi. Rather than resembling a "native dance" one might actually encounter in the New Zealand of the mid-1920s, or indeed the titillating spectacle of nativity frequently encountered onscreen, Kiwi's dance refers to the gestural performance of a romantic movie heroine. She is seen to incorporate and to embody the acts of cultural translation which elsewhere occur as a function of cinema's vernacular, dancing between (authentic) culture and cinematic spectacle. 


\section{"Make Up And Get Into Your Maori Costume Quick!"}

While Kiwi is certainly presented as exceptional, she also points to the larger effort in what has been described as "recolonial" New Zealand to express national distinction via appropriations of the "native." ${ }^{28}$ In this context, dance provides visible evidence of a local and distinctive culture, serving proto-national settler narratives. This context distinguishes Kiwi's dance from other displays of the "primitive" circulating in the global cinema circuit, featuring indigenous or nonindigenous performers. In the latter category, Asta Nielsen's "gaucho dance" in the 1910 Danish film Afgrunden, and Marlene Dietrich's "Hot Voodoo" number from Blonde Venus offer two examples, perhaps the most prominent in feature film, of Kiwi's "type": the "white woman who can dance the native dance." ${ }^{\prime 2}$ However, Dietrich and before her Nielsen loosely evoke a racial other not only by nomination and costume, but in support of an association between racialised primitivism and unruly female sexuality; Kiwi, on the other hand, blithely performs the "native," and in so doing claims a specific culture, a home, a right to settle ${ }^{30}$ In contrast to the "ultramodern primitivism" represented by Josephine Baker, the racial masquerade offered by Dietrich and others, or the "ethnographic" titillation of "native" bodies on screen, Kiwi's performance then offers a path to modernization via the settler-colonial appropriation and display of local-indigenousculture. ${ }^{31}$ It is novel as modernity demands, rather than for the act of cultural appropriation that it represents.

The role of Kiwi was performed by Bathie Stuart, an actress who had already made a small name for herself in the "comedy musical show" Bathie Stuart and her Maori Maids. ${ }^{32}$ Her abilities, according to a writer at Wellington's Evening Post of 18 November 1925, were acquired through "years of study and association," such that "[i]n the dances ... she has all the lissome grace of the native-born and has many times been taken for a Maori by those who have witnessed her performances. ${ }^{33}$ Here, we are offered the dueling ideas that this figure of the settler-indigene, the Pākehā native-dancer, is new and exceptional — a novelty — and that it is a figure forged through settlement, and thus replicable, a new norm. In fact, Kiwi piggybacks on a strong tradition of Māori cultural performance, and on the cross-cultural "study and association" common from the earliest days of colonization. ${ }^{34}$ Māori performers were active in popular cultural settings from the earlynineteenth century on, both locally - at sites like Whakarewarewa, and in music and church halls throughout New Zealand - and globally, as far afield as Sydney, London, and even New York, with performance histories suggesting that "Māori saw themselves as partners in colonial development rather than as subjects of it." ${ }^{35}$ The portrait painted of Bathie, meanwhile, is of an earned indigeneity, emphasizing knowledge of the colonized culture as much as personal contact. This knowledge, it is worth noting, is held in the body and expressed in performance: Bathie is only "taken for a Maori" when she performs. Likewise, culture is seen as apperceptible via display; thus, it is in cultural display that acts of cultural translation can occur. Bathie/Kiwi is significantly not Māori, but is insistently framed as indigenized: possessing knowledge of "the local world."36

Despite Kiwi's own native "lissome grace," she still requires accessories to fully inhabit her role, a condition supporting spectacular display, as well as the idea that indigenous culture is appropriable, like a thing. At the film's narrative and emotional peak, when we see her dance on the Sydney stage, accessories are essential for her to fulfill her promise as a modern cultural ambassador and as a star. She takes to the stage only after the sacrifice of a loyal friend: Murray's sometime fiancée, Mollie, who having followed him to Sydney from London is coincidentally employed as a chorus girl in Kiwi's revue. Murray makes one final attempt to win Kiwi over, buying the show and imploring her: "Let me make you a star, as well as my wife!" Spurned, he

Journal of New Zealand Studies NS25 (2017), 40-56 
seeks "to break [Kiwi's] spirit, and bring her in utter subjection to his feet" - by insisting that Mollie appear in her place. Mollie's response - feigning drunkenness in order to make herself unfit to perform - clears the way at the eleventh hour for Kiwi to take her rightful place at centre stage. "Make up and get into your Maori costume quick!" the producers demand. "You're going on!" What makes Kiwi a star is, no doubt, the "novelty" and talent she represents; nonetheless, she is ably assisted by her "Maori costume," which she wears for every dance performance, no matter how improbable.

When Kiwi first appears on screen, dressed for dinner, Murray gives us an indication of the transformative, alluring power of that costume. "Can you forgive me for my rudeness this afternoon?" he asks, evidently recovering his manners when faced with Kiwi in her evening gown. "You were such a fascinating little thing in that Maori costume that I quite lost my head." Kiwi's response - "I really don't know whether to take it as an insult or a compliment"-is ambiguous, but her strategy is consistent. When she first dances in the sitting room, she does so in costume; when she runs to the model village to seek solace with her friend Mary she changes out of her day clothes before setting off; on stage, she is pictured in a variety of korowai and piu-piu; and when she dances in the final scene, surprising Algy in his home, she quite miraculously appears from a doorway dressed for the dance, although moments before she had arrived in street clothes and evidently without baggage. Likewise, when Algy dreams of Kiwi, he dreams of her in costume, animated in her dance, and he maintains a small shrine to her in his home - a photographic portrait framed with piu-piu and native fern fronds. The "Maori costume" assumes a fetishistic status, where Kiwi's settler body will not.

Kiwi is, then, quite literally framed as "native" with accessories furnished by Māori material culture, one instance of how more generally "the self-fashioning of Pākehā was framed by Māori symbols." 37 In Kiwi's case, this extends beyond symbols to tangible objects. In her eagerness to put on her Māori costume, Kiwi demonstrates the idea that she is taking on the role of representing an object culture; she demonstrates not only the "native dance" but the idea that "to be native" is to be in possession of knowledge of, and things originating in the local world. This reflects a longstanding equation of the indigenous with the material, and natural. It is an equation restated in every use of Kiwi's name, cementing her claim to be representative: to be both settled, and a means to settle; to be a local. In this sense, Kiwi provides a kind of an answer to the settler's dilemma: that is, how to be at home when faced with the stubborn facticity of the indigenous people.

Kiwi acts as an eager guide to indigenous culture in an environment in which cultural appropriation was an established fact. As the film deploys symbols of culture to make Kiwi's claim visible, it enacts a colonial discourse: that is, a discourse that "produces the colonized as a fixed reality which is at once an 'other' and yet entirely knowable and visible." 38 This quality of being knowable is what enables Kiwi's performances. She knows "the native" and, further, makes the native knowable, such that Māori themselves are largely absent from the film. Each time she puts on her Māori costume, Kiwi provides an opportunity for cultural encounter in the most denatured terms. To be fair, the film presents a slightly more complex attitude toward its one named Māori character than this might indicate, albeit one evidently born of expedience. MaryKiwi's "old Maori friend"-provides a convenient proof of the premodern in the model village, licensing Kiwi to take on the role of cultural ambassador through her invitation to dance and her willingness to remain silent, and still; concurrently, Mary proves herself to be a modern, literate subject, as well as a friend when her name appears on a telegram Kiwi receives in Sydney advising

Journal of New Zealand Studies NS25 (2017), 40-56 
her of her father's death. On the whole, however, Māori people are incidental in this narrative, displaced and subsumed into proofs of authenticity, a performance culture ready to slip on, like a costume, for the modern stage.

\section{"It's Wonderful, How Like Sydney Wellington Is!"}

By the time Kiwi takes to the stage, we understand her to occupy multiple roles. She is a settled "New Zealander" and a means for Algy to settle through marriage; a subject with the ability to travel between the farm, the model village, and the Sydney stage; and, of course, a dancer. It is not coincidental that Kiwi's modern mettle is tested in Sydney, still a regional metropolis for New Zealanders seeking the pleasures of modern life. By the period in question, it had taken its place among the "modernizing capitals of the world." 39 In Jill Matthews' study of Sydney's "romance with modernity," Dance Hall and Picture Palace, she writes that "moving pictures and social dancing" were the "two entwined elements of popular culture that were central to the emerging modern social and moral economy," with Sydney from the early-twentieth century "only a season behind America" in the latest dance and fashion trends. ${ }^{40}$ Thus, a move to Sydney is required before Kiwi's dance finds its place in a truly modern public sphere. London, in the film, consists of an interior view of an office, and Paris is simply a proof of Murray's dishonesty. Sydney, on the other hand, furnishes a modern, and accessible metropole.

Dance was not only central to Sydney's local engagement with modernity, but expressive of more global social and cultural transformations, of the embrace of novelty and curiosity for the new which modernity - "the ephemeral, the fugitive, the contingent"-by definition demands. ${ }^{41}$ According to Erin Brannigan, modern dance offered a way of translating modern experience that would exceed early cinema's capacity to do so. This is because of the dancer's ability, in a modern environment in which the "human body was ... figured as under duress," to act as a "cultural influence that was translating the forces of technology - along with new notions of the moving body and movement itself ... into an influential artistic force." 42 The dancer, that is, embodied the environmental and sensory stresses that are seen to be emblematic of the experience of modernity, capturing in ephemeral, contingent movement the spirit of the age.

In The Adventures of Algy, however, the modern "body ... under duress" is not the dancing Kiwi's, but Algy's own. As he arrives in New Zealand the film pokes fun at the primitivist romances that would place "Maoriland" in a premodern past, and at the tourists who might believe them. A point-of-view shot of a canoe manned by bare-chested Māori (some in modern trousers) gesticulating vigorously with their spears allows us a glimpse of the world that "Maori Histories [he] had read on the voyage" lead Algy to expect. As Algy himself might put it, he's spared this end. The "wilds of Queen St" are dangerous for their crowded "safety zones"; his efforts to negotiate traffic see him jammed between commuters and falling from a tram before he's eventually carried off, perched on a car. Modernity, that is, also lives here.

Algy's visit to New Zealand thus provides the opportunities for the most modern of experiences: namely visual tourism, (more "padding"), of a kind which characterized Government Publicity Office (GPO) films made in the period, and which seems designed to appeal to the home crowd. ${ }^{43}$ According to an advertisement in the Press:

All corners of New Zealand are picturised: Maori Men and Maidens, Rotorua's Gorgeous Grandeur, the Streets of Wellington, Bathing Beauties at Lyall Bay, the Kelburn Car, the Romance of Busy Sydney, Cycling in Christchurch, Taranaki's Oilfields, Dunedin's Pie 
Cart, Algy's Crossword Puzzle, Gorgeous Theatre Scenes, and Maori Dances all helping to make a Fine Comedy Romance. ${ }^{44}$

The description slips between the geographical and the cultural, between the local site and the cinematic staple; "Busy Sydney" takes its place next to "Dunedin's pie cart," "Algy's Crossword Puzzle," and "Maori Dances." Appropriate to an "Australian-New Zealand comedy-romance," it suggests an obliging quality of being complete, its roll call of local attractions defined most of all by their currency - once made visible by cinema-in a modern, transactional system of entertainment and display.

To be, as Jonathan Dennis claimed of the film, "very much of its time and place," thus means not just to speak in the vernacular, but to speak the modern language of commerce. ${ }^{45}$ Appropriately, many of the film's gags are drawn from and explicitly reference consumer culture. Pining for Kiwi, we're told that Algy "even tried Aspros to soothe his aching heart"; a shopping trip Algy makes in Sydney is the pretext for comedy, as well as evidence of his pliable, goodhearted nature. An advertisement taken out by the film's entrepreneurial producer-director Beaumont Smith makes its integration into consumer culture even more evident. In a full page in Everyone's - a leading Australian entertainment and moving picture magazine-Smith is depicted as a puppeteer, his two stars dangling from his controlling grip against a scenic background featuring a whare nui under the exhortation to "Buy Australian Goods." "Gentlemen" he announces, "I have just opened up my new season's goods, namely, 'The Adventures of Algy,' and they are at present being displayed at the Lyceum and Lyric Wintergarden, Sydney. I have noted the trend of public taste, and my new offering contains all that is necessary to make a popular appeal." ${ }^{26} \mathrm{Kiwi}$, typically, is dressed in her Māori costume, Algy as an "Englishman," with monocle and top hat: two exotic "types" on display. ${ }^{47}$ One could see their fate as a symptom of the plight of the modern body "under duress," buffeted by forces beyond its control, but it mostly conveys a sense of the film's opportunism: the extent to which it is seen, even more than a product, as a bill of goods. In this sense it reveals its modern aspirations and ethos, no less than a more formally innovative work, by siting itself firmly as the result and representation of a local consumer culture: "all that is necessary to make a popular appeal."

Just as the film is seen to be transactional, its stars are depicted as bankable goods - puppets available for manipulation and display — and thus as desirable and substitutable as mass consumer goods are. It is an attitude toward the stars that mitigates against them fully inhabiting their roles; rather, they offer access to the larger local consumer culture. The film opens, pre-titles, with an extreme close-up of Claude Dampier's head - the only such shot in the film - as he turns ninety degrees to face the camera. It recalls the "attractional" cinema's non-narrative qualities, only here - in place of a "direct assault on the spectator" of the kind seen in the famous look to camera which ends Edwin S. Porter's The Great Train Robbery twenty-two years before, which this shot recalls - we seem to encounter something like a direct appeal to the spectator to recognize and validate the entertainment to come. ${ }^{48}$ Claude Dampier may well have been recognized: he toured New Zealand and Australia in vaudeville before, during, and after the release of the film. Local newspapers report appearances as early as 1912, with Dampier appearing regularly as a headliner from 1922. By 1924, he is being described as a comedian of the "silly ass" type," in association both with his role in Beaumont Smith's previous picture, Hullo Marmaduke (1924), and with his vaudeville act. The Otago Daily Times wrote that "Mr Dampier ... has perfected this Johnnie type to such a perfect degree that he is its recognised exponent, and a comedy idol throughout Australia

Journal of New Zealand Studies NS25 (2017), 40-56 
and New Zealand." 49 What looks like an awkward departure from narrative style in the initial close-up of Mr Dampier's face thus indicates an appeal to a local entertainment circuit in which he, as well as his "type," were seen already as bankable "goods."

His character, Algy, himself has all the characteristics of a modern subject: he is, or is soon to be a landowner; his destiny is his own to make; he is drawn to novelty and adventure; he profits (in the discovery of oil) from modern advances in technology. Nonetheless, time and again, Algy proves incompetent to navigate the modern world; time and again he is found under duress, arriving late, and out of place. Once in Sydney, he's slipped a mickey by his more worldly cousin Murray, and Algy is "deserted like an unwanted child left on a doorstep." Murray leaves Algy to miss the boat to New Zealand; when he does awake, he stumbles onto the commuter ferry at Circular Quay. He makes the trip in circles, clutching his blanket, and disembarks in the place he started, again to the amusement of the locals. "It's wonderful," he remarks," how like Sydney Wellington is!" Rather than the ennui of the world traveller, we know this to reflect the perspective of a naif. The film's local knowledge insists on their difference, even as they are understood to be equally modern; meanwhile, Algy demonstrates that coming from the colonial centre is no guarantee of modern savoir faire. Even out of the city, Algy fails to cope well with modern life. Thus, near the end of the film, after his discovery of oil has restored his own fortunes and rescued Kiwi from Murray's clutches again, he finds himself in mortal peril thanks to Murray's plan to "humiliate him and disgust Kiwi at the same time." In a scene that recalls the "chase films" of early cinema, (and which is repeated in a series of "community comedies" made in regional centres in New Zealand in 1927 and '28), Algy is pursued by "more than a dozen wild women...!," set off by an ad at the newsagents and spurred on by Murray's eager hand. ${ }^{50}$ Even his crossword (itself a distinctly modern phenomenon) almost gets the better of him in a running gag that paces the film and decides the outcome of Kiwi and Algy's fledgling romance. All manner of modern experiences thus find their way into this "bill of goods"; all forms of modern circulation and sociability confound and outdo poor Algy. Traffic, media, commerce, and mass amusements leave him exposed, and out of place.

And Kiwi? Kiwi proves herself to be more at ease in the modern world than Algy, but- to return to Brannigan's formulation - her dance does not translate the experience of a modern "body under duress" not because of her apparent facility with modern mores, but because her dance is not, in itself, modern. Dance, it should be stressed, acts for Kiwi as a means of cultural and geographical mobility and therefore as modern in its effects. However, while the "novelty" Kiwi represents suggests a definitively modern ideal, the basis of its novelty is in her person dancing, rather than in the dance itself. That, we're told, is "native"- the opposite of "modern."

Whether her dance is in fact representative of Māori cultural practices is not particularly relevant to this claim. It can be said that not only is her dance narratively 'not modern,' it is also aesthetically so. Modern dance, as a genre of performance, has roots in classical ballet but departs from ballet in its use of the dancing body as, in Erin Brannigan's words, "transformative" rather than representative. Of modern dance of the period, Brannigan writes:

This was nonmimetic dance, departing from the character-based performances of narrative ballets and the generic dance steps of burlesque and vaudeville, both of which depended upon engaging or alluring personalities and role-playing.... [The modernist] dancing body was a radical intervention within a history of female performance based around characterization, titillation, idealization and voyeurism. ${ }^{51}$ 
Kiwi's dance, on the other hand, is a consequence and effect of characterization. That is, for her there is no dance without role-play. Her nomination as a "novelty" based on her dancing makes the significance of characterization for Kiwi's persona as a dancer explicit; it is reiterated by the requirement that she is always in costume to perform. In fact, her assumption of the costume seems to quite transport Kiwi herself, making her the object of voyeurism, but also removing her from her immediate environment. Her response to Murray's approach during her dance in the sitting room, when she carries on despite being clasped from behind, is thus mirrored in the final scene of the film. Having returned from Sydney, Kiwi goes to Algy's house, presumably to secure their union. Algy, wandering in from the garden with his crossword, chances upon her dancing now in his sitting room, once again lost to the world. As he advances on her, his arms held wide in repetitive gestures of admiration, she keeps on dancing, fully in character. Her appearance is as it was in Algy's imagination when earlier in the film he dreamed of her presence. She is at once in, and set apart from the world, a serenely smiling, gesticulating emblem of the indigene.

Kiwi's dance as role-play here offers a series of poses as the representation of a whole: namely, the "native" which her dance allows her to apparently embody and represent. As Brannigan indicates, posing and role-playing are associated with a premodern style of dance performance. This is not to suggest that Kiwi's dance is authentically "primitive." Rather, the movements of her dance are strongly mimetic: here she gestures toward the sky, there she displays her familiarity with poi. She proceeds by way of a series of poses, each movement freighted with "as if." In this way, her dance presents a calcified view of culture, in which it is understood to be perceptible as an artifact rather than as a process. This may go some way to explaining Kiwi's extraordinary self-possession. Rather than seeing the body as a "transformative site," registering the effects of modernity through dance, Kiwi's performances suggest that her body is a vessel for the containment and resuscitation of a preexisting cultural tradition. In this sense, it recalls the cinematic treatment of native peoples and cultures that Fatimah Tobing Rony has described as "ethnographic "taxidermy":: "the effort to make that which is dead look as if it were still living." 52 Kiwi's dance generally remains the same, without influence from environmental forces or even active suitors, because-despite its modern flourishes - the idea of the dance is as if it were fixed in time, and revivified through her dancing, present body.

If Kiwi's dance performances suggest she is immune to the stimuli offered by her immediate surroundings, her performance style is nonetheless enabled by her larger cultural context. While her dance seems to refer to tradition, her dancing occurs in the modern world; what is more, it is made more modern by the increasingly "modern" environments in which it occurs. Theories linking movement and cinema consistently draw on the idea that each is shaped by, and perceptible in terms of, its modern environment. Gilles Deleuze argues that the conception of movement as "the regulated transition from one form to another ... an order of poses or privileged instants, as in dance," was replaced by a modern sensibility which viewed the fixity of the pose as outdated. ${ }^{53}$ This sensibility could be seen both in the performance styles of modern dancers and in the cinematic technology which brought such dance to global audiences, itself a technology of movement. Modern dance can be seen to work toward the same ends as cinema when it is "capable of reacting to the accidents of the environment," rather than seeking to reproduce or embody a preexisting whole. ${ }^{54}$ In this much, Deleuze's conception of the "movement-image" recalls Béla Balász's early film theory, which focused on the modern environment as the site for a new "language of gestures" to be enabled by and realized on film. ${ }^{55}$ Not coincidentally, Asta Nielsen's famous "gaucho dance" in Afrgunden is Balász's best-known example of gestural language: just as Kiwi's dancing body stands in for the 
"native" in her dance, Nielsen, at the emotional climax of the film, makes "use of her own body to substitute for and repress experience of the "Apache" woman she mimics." 56 In her study of Balász's film theory, Erica Carter emphasizes that the "new filmic body "which would result, and which for Balász Nielsen's dance epitomizes, "is not equivalent to the prelapsarian body of 'primitive' or folk cultures"; rather, his "utopian modernism" had its basis in a "cultural process" of perception and cognition in which the 'gait and everyday gestures' of figures encountered on the street, in the family home, and in the moving image are recognised, consciously remembered, then absorbed to become an "instinctive sensibility ... materialized as culture in the body." 57 The modernity of both dance and cinema thus reside in their shared ability to return lived experience to the body, reanimating and representing a world which rapid change has made perceptible only in glimpses. However, Kiwi's dance sets her apart from the world, and takes her out of her culture; it also lacks any of the sensuality and cosmopolitan tension of Nielsen's dance. In these ways, it cannot be seen as modern. What appears as novelty relies on the performance of archetypes: on the fixed rehearsal of a series of poses.

Fashioning dance as an artifact reflects colonial practices for the display of indigenous material culture, rather than according with what was seen as the modern capacity of both the dancing body and the cinematic apparatus to capture, and to participate in the mobility and flux of modern life. ${ }^{58}$ However, while Bathie's dance may stand alone (and she with it), it also takes place in the context of the "Australian-New Zealand comedy-romance" which sites this text emphatically in the time and place of its making. The question here, in fact, is not so much whether Kiwi's dance is modern, but how best to understand the significance of her modern environment as it might shape her dance. This environment includes the non-diegetic cultural landscape, and the generic cinematic terrain in which the film audience encountered her dance, as well as the local sites in which Kiwi is depicted dancing. Despite her self-possession, and the consistency of her dancing style, the film presents us with a situation in which the dance itself signifies differently - and in particular, as modern in different ways - in different performance spaces. Nowhere is this clearer than in the scene in which Kiwi finally takes to the Sydney stage.

We see the show unfold exclusively as a series of tableaux of Kiwi's triumphant dance performances. She rushes on stage, dressed in a more elaborate costume than usual. For the first time in the film, she dances in a group, at the centre of a troupe of chorus girls, their bobbed hair and spritely demeanour associating them with Sydney's modern scene. While Kiwi's movements are broadly similar to those she has displayed in her previous dances, they assume a different meaning when placed at centre stage, surrounded by other dancing figures. The chorus girls' dress and style of dance, moreover, differs from Kiwi's in small but telling ways, shifting the emphasis from a Māori, to a more generically mimetic "native" performance style. In one part of the dance, they appear en pointe (Kiwi still in her court shoes); in another they wear lei, and skirts which riff on piu-piu made with marabou; in still another they wear fuzzy wigs, prefiguring those famously worn by Marlene Dietrich and her chorus in the "Hot Voodoo" number of Blonde Venus. The effect overall is extravagantly inclusive; it is, as Jonathan Dennis put it, "a marvellously bizarre vaudeville amalgamation of ballet, fan, Māori and even Cossack dances.", 59

Despite the dance's glorious incoherence, what stands out most of all is the theatre space in which it occurs. Although it signifies as the apex of Kiwi's achievement, and the confirmation that she has become-independent of Murray - a "star," the sequence contains no close-ups of Kiwi herself, but is almost entirely in extreme long shots favouring the corps of dancers, the shapes their bodies make on stage, and the stage crowned by an elaborate proscenium arch. Cut-aways reveal

Journal of New Zealand Studies NS25 (2017), 40-56 
Algy in medium close-ups, making a nuisance of himself from his seat in the stalls, but Kiwi, the star of the show, is seen from a distance. Her achievement here is to be a figure in a modern landscape, halfway to a Tiller girl, modern by virtue of the scene she's in. In her influential analysis of Marlene Dietrich's extraordinary performance in Blonde Venus - in which Dietrich removes a gorilla suit to appear bewigged and ornamented in "native" style like the dancers in blackface behind her-Mary Ann Doane argues that race, in twentieth-century modernity, emerges not as essence, but as performance: "an erotic accessory to whiteness. The black woman ... becomes the white woman's mise-en-scene." ${ }^{60}$ This may be true for Kiwi, too-remember Mary, her enabling static friend, as well as Kiwi's abundant "native" accessorisation. However, what is most striking about Doane's analogy for Kiwi's stage appearance is the significance of mise-en-scene in more conventional terms. We see that Kiwi achieves the status of a modern girl, and star, because she is on stage, rather than the reverse; the stage, rather than the dancer, is evidence of the modern scene in which Kiwi circulates. The space, then, further accessorises the dance, and thus changes its meaning.

Perhaps as a marker of just how modern this scene is, we find out-following Kiwi's triumphant performance - that the theatre is to be closed down, "turned into a picture house." Nothing, that is, stays still. The news is barely necessary to the plot, except to push Kiwi homewards. We know that she can be a stage star, but movie stardom is clearly beyond her reach. The moment reflects a kind of nostalgia for the embodied experience of space: for the thrill of performing on stage. Losing that stage, however, Kiwi goes home to find another in domestic space; it is at this point in the narrative that she dances for Algy for the last time, appearing magically in his sitting room, dancing in front of the shrine to her found there, and providing the final clue to his crossword: LOVE.

Another movie might have had Kiwi continue her ascent, stay in Sydney, come to a bad end. Perhaps the reason that Algy does not is that it was, in the end, quite determined to be "one of ours." Kiwi, that is, needed to end up a Kiwi in order for the film's larger story of settlement to play out. Just as modernity is everywhere "decisively at large, irregularly self-conscious, and unevenly experienced," the film thus also attests to the self-consciousness and irregularity of colonial discourse. ${ }^{61}$ It describes, as Nicholas Thomas puts it, a "practically mediated relation": a cultural process, rather than a coherent imposition of colonialism's forceful rule. ${ }^{62}$ In this sense, Kiwi's dance - as it is visible and embodied, as it is a performance, and as it stands in for a more diverse vernacular culture - offers an apt metaphor for the process of becoming which constitutes both modernity and colonialism in their various local sites and modern spaces.

In her discussion of vernacular modernism, Miriam Hansen argues that her subject, the classical Hollywood cinema, "offered something like the first global vernacular ... because it played a key role in mediating competing cultural discourses on modernity and modernization, because it articulated, multiplied, and globalized a particular historical experience." ${ }^{\prime 63}$ Clearly, Algy is rather more vernacular than global in its appeal. Even as it engages with global forces, and calls on shared or borrowed modern resources, it is doggedly of its place and time. The film registers and narrates a small-scale, globally insignificant modernity that responds to a set of conditions that present as discursively continuous, ("the modern"), but are realised in distinctive ways in this particular locality ("a modern"). Algy does localizing work in mediated space.

It does this work by profiting from the trend for primitivism characteristic of silent cinema's global circuits of production and reception, and by insisting on indigenous culture as artefactual, the cultural patrimony of a settler colonial state. It bears repeating that the modern is, everywhere, laced

Journal of New Zealand Studies NS25 (2017), 40-56 
with primitivism. Algy, particularly, proves itself to be of its place and time- to be modern and vernacular-by citing, borrowing from, and simply misrepresenting elements of Māori cultural display. This occurs most notably in association with Kiwi McGill, its heroine and object of desire, its dancer of the native dance. At the same moment, the film recognizes - in a way which is quite unique amongst its peers - that the fantasy and transport enabled by the pictures also plays out in real spaces: in the small towns and cinemas, in the shopping streets and theatre stages, in the model village and the homes of its local places.

\footnotetext{
${ }^{1}$ Beaumont Smith, The Adventures of Algy, 1925. For a list of films made in New Zealand in the silent period, see Jonathan Dennis and Paolo Cherchi Cherchi, Aotearoa and the Sentimental Strine: Making Films in Australia and New Zealand in the Silent Period (Wellington: Moa Films, 1993); and for a more recent list of films made by filmmakers resident in New Zealand, Peter Limbrick, Making Settler Cinemas: Film and Colonial Encounters in the United States, Australia, and New Zealand (New York: Palgrave MacMillan, 2010), 43. I am aware of two other features from New Zealand's silent period that were set in contemporary society. One-Rudall Hayward's The Bush Cinderella, 1927-features no Māori characters; the other-Gustav Pauli's Under the Southern Cross, 1927, which no longer survives and is not to be confused with the (also lost) 1929 Universal Pictures film of the same name-told an immigrant love story in which Māori were seen to live in the present day.

${ }^{2}$ Huia Mase, Outrageous Fortune (London: Robert Hale, 1971), 44.

${ }^{3}$ The film shoot was accompanied by a series of "screen tests," in which "aspiring screen types" acted out maudlin scenes on the stage of their local picture theatre, supposedly to be considered for the stardom, but more likely for the quick return generated when they returned to see themselves on screen the following week. Ibid., 43-44.

${ }^{4} \mathrm{He}$ carried on to describe it as "a local folk film, very much of its time and place." Jonathan Dennis, Audio recording, 16 June 1988, Ngā Taonga Sound and Vision.

${ }^{5}$ Marshall Berman, All That is Solid Melts into Air: The Experience of Modernity (New York: Penguin, 1988), 1.

${ }^{6}$ Chicago Herald and Examiner, 15 October 1930, Tourist and Publicity Department Files - TO 5/3 pt.1 Bathie Stuart, National Archives of New Zealand.

${ }^{7}$ Terry Goldie describes "indigenization" as an "impossible necessity" for settlers, in Peter Gibbons, "Cultural Colonization and National Identity," New Zealand Journal of History 36, no. 1 (2002): 5-17.

${ }^{8}$ See George Stocking, "The Ethnographic Sensibility of the 1920s and the Dualism of the Anthropological Tradition," in The Ethnographer's Magic and Other Essays in the History of Anthropology (Madison, WI: University of Wisconsin Press, 1992), 286; Fatimah Tobing Rony, The Third Eye: Race, Cinema, and Ethnographic Spectacle (Durham: Duke University Press, 1996), 148. ${ }^{9}$ Miriam Bratu Hansen, "The Mass Production of the Senses: Classical Cinema as Vernacular Modernism,” Modernism / Modernity 6, no. 2 (1999): 60.

${ }^{10}$ See Mette Hjört and Duncan Petrie, The Cinema of Small Nations (Bloomington, IN: Indiana University Press, 2007). Note that the chapter on New Zealand filmmaking makes no reference to films made before 1940, with its real discussion beginning in the 1970s, as has been common in histories of New Zealand film.

${ }^{11}$ Arjun Appadurai, Modernity at Large: Cultural Dimensions of Globalization (Minneapolis: University of Minnesota Press, 1996), 180.

${ }^{12}$ Jennifer M. Bean, Anupama Kapse, and Laura Horak, eds., Silent Cinema and the Politics of Space (Bloomington, IN: Indiana University Press, 2014).
}

Journal of New Zealand Studies NS25 (2017), 40-56 
13 “Sydney's Recent Film Releases. Dependable Opinions," Everyone's, 24 June 1925, Adventures of Algy File, Ngā Taonga Sound and Vision.

${ }^{14}$ The film, now in fragments, recorded a visit intended to reward the colony for its service in the Boer War. Royal Visit of the Duke and Duchess of Cornwall and York to New Zealand, 1901, 1901. Lawrence Wharerau notes that it is not only the first government film made in New Zealand, but the "oldest surviving film record of Māori known to exist anywhere in the world." In Diane Pivac, Frank Stark, and Lawrence McDonald, eds., New Zealand Film: An Illustrated History (Wellington: Te Papa Press, in association with the Film Archive, 2011), 39.

${ }^{15}$ See Dennis and Cherchi, Aotearoa and the Sentimental Strine, 7. The Government Publicity Office (GPO) started making films in 1921, and was in regular production from 1923. See Jonathan Dennis, ed., The Tin Shed (Wellington: New Zealand National Film Unit; New Zealand Film Archive, 1981), 7-8. GPO filmmakers in the 1920s were instructed to avoid shooting people, to prevent them "being dated by changes in fashion." See Dennis and Cherchi, Aotearoa and the Sentimental Strine, 9.

${ }^{16}$ Martin Blythe, Naming the Other: Images of the Mãori in New Zealand Film and Television (Metuchen, NJ and London: The Scarecrow Press, 1994), 50.

${ }^{17}$ Patrick McInroy, "The American Melies," Sight and Sound International Film Quarterly (Autumn 1979): 254.

${ }^{18}$ Emile de Brigard, "The History of Ethnographic Film," in Principles of Visual Anthropology, ed. Paul Hockings (The Hague: Mouton Publishers, 1975), 19. While in New Zealand, Méliès also made several documentaries, and two more narrative films featuring Māori actors and themes. One was a version of the legend of Hinemoa and Tutanekai; George Tarr made a film of the same story in 1914, (the first feature film made by a resident New Zealander), as did the Danish director Gustav Pauli in 1927. Dennis notes that Méliès' films were never released in New Zealand. Dennis and Cherchi, Aotearoa and the Sentimental Strine: Making Films in Australia and New Zealand in the Silent Period, 7.

${ }^{19}$ Lew Collins, Under the Southern Cross (Universal Pictures, 1929); Gustav Pauli, The Romance of Hinemoa (Gaumont, 1927); “Amusements. Mr Hull's Pictures," Alexandra Herald and Central Otago Gazette, 15 January 1930, Papers Past; “"Hinemoa' Native Love Story Filmed,” Press, 9 March 1928, Papers Past. The initial screenings of The Adventures of Algy in Sydney were likewise accompanied by performances from a troupe billed as "Princess Rangiriri and her Maori Maids." "Adventures of Algy Advertisement," Everyone's, 24 May 1925, Adventures of Algy File, Ngā Taonga Sound and Vision. ${ }^{20}$ For discussion of modern anthropology's bias toward "visualism" see Johannes Fabian, Time and the Other: How Anthropology Makes its Object (New York: Columbia University Press, 1983), 106; James Clifford, "Introduction: Partial Truths," in Writing Culture: The Poetics and Politics of Ethnography, ed. James Clifford and George E. Marcus (Berkeley, Los Angeles, London: University of California Press, 1986), 12.

${ }^{21}$ George Tarr, Hinemoa, 1914; Pivac, Stark, and McDonald, New Zealand Film, 61.

${ }^{22}$ James Clifford, The Predicament of Culture: Twentieth-Century Ethnography, Literature, and Art (Cambridge, MA: Harvard University Press, 1988), 22, 26.

${ }^{23}$ Conal McCarthy, Exhibiting Māori: A History of Colonial Cultures of Display (Oxford and New York: Berg, 2007), 2.

${ }^{24}$ Rony, The Third Eye, 43.

${ }^{25}$ Lesley Brown, ed., "Romance," Shorter Oxford English Dictionary on Historical Principles (Oxford and New York: Oxford University Press, 2007). In this, the films demonstrate what Johannes Fabian calls the "denial of coevalness." Fabian, Time and the Other, 31.

${ }^{26}$ Rony, The Third Eye, 148.

${ }^{27}$ Thus Under the Southern Cross (1929) contains an intertitle instructing viewers to "Forget your hatreds in the dance of the Ha-Ka," converting a context-specific, ritual declaration of war to an opportunity to let your hair down. Collins, Under the Southern Cross.

${ }_{28}$ James Belich, Paradise Reforged: A History of the New Zealanders from the 1880s to the Year 2000 (Auckland: Penguin, 2001). Belich writes that "signs of the Pakeha co-optation of Maori culture" were 54 Journal of New Zealand Studies NS25 (2017), 40-56 
evident from the 1890s, and "really took off from the 1900s" $(209,329)$. Macrons are absent in the original.

${ }^{29}$ Urban Gad, Afgrunden / The Abyss (Kosmorama, 1910); Josef von Sternberg, Blonde Venus (Paramount Pictures, 1932).

${ }^{30}$ The next local equivalent-Laya Raki's dance performance in the 1954 film The Seekers, in which the German-Javanese actress played a Māori woman —was, however, "highly eroticized." Limbrick, Making Settler Cinemas, 92.

${ }^{31}$ Patrice Petro, "The Hottentot and the Blonde Venus," in Aftershocks of the New: Feminism and Film History (Brunswick, NJ and London: Rutgers University Press, 2002), 140.

32 Julie Benjamin, "Story: Stuart, Bathia Howie. From the Dictionary of New Zealand Biography," Te Ara - the Encyclopedia of New Zealand, accessed November 16, 2016, http://www.TeAra.govt.nz/en/biographies/4s52/stuart-bathia-howie.

33 "Paramount Theatre," Evening Post, 18 November 1925, Papers Past.

${ }^{34}$ James Belich, "The Maori Discovery of Europe," in Making Peoples: A History of the New Zealanders From Polynesian Settlement to the End of the Nineteenth Century (North Shore, NZ: Penguin, 2007), 251-54.

${ }^{35}$ McCarthy, Exhibiting Māori, 38. See, for accounts of cross-cultural performance and travel, Belich, "The Maori Discovery of Europe"; Margaret Werry, The Tourist State: Performing Leisure, Liberalism, and Race in New Zealand (Minneapolis: University of Minnesota Press, 2011); Marianne Schultz, "The Best Entertainment of Its Kind Ever Witnessed in New Zealand': the Rev. Frederick Augustus Bennett, the Rotorua Maori Entertainers and the Story of Hinemoa and Tutanekai," Melbourne Historical Journal 39, no. 1 (2011): 31-53, macron missing in the original; Marianne Schultz, "A 'Harmony of Frenzy':

Māori in Manhattan, 1909-10," Theatre Journal 67, no. 3 (October 2015): 445-64.

${ }^{36}$ Gibbons, "Cultural Colonization and National Identity," 8.

${ }^{37}$ McCarthy, Exhibiting Mãori, 39.

${ }^{38}$ Homi K. Bhabha, "The Other Question: Stereotype, Discrimination and the Discourse of Colonialism," in The Location of Culture (London and New York: Routledge, 2004), 101.

${ }^{39}$ Hansen, "The Mass Production of the Senses," 65.

${ }^{40}$ Jill Julius Matthews, Dance Hall and Picture Palace: Sydney's Romance with Modernity (Sydney: Currency Press, 2005), 85.

${ }^{41}$ Charles Baudelaire, "The Painter of Modern Life," in The Painter of Modern Life and Other Essays, trans. Jonathan Mayne (London: Phaidon Press, 1964), 13.

${ }^{42}$ Erin Brannigan, Dancefilm: Choreography and the Moving Image (New York: Oxford University Press, 2011), 21.

${ }^{43}$ Thus, the New Zealand Free Lance of Wednesday, 8 April 1925, reported: "Several comedy scenes have been made on the station at Henderson, and also at Glen Eden, where the 'movie actors' provided a source of amusement for the whole township, who turned out en masse to see the fun," while The Dominion of Tuesday, 31 March 1925, revealed that large crowds turned out to see the secret behind the "hat trick" in the Wellington scene: "a long length of cotton, which was cleverly manipulated by the producer." Adventures of Algy file, Ngā Taonga Sound and Vision. For discussion of visual tourism in New Zealand's government films, see Alfio Leotta, Touring the Screen: Tourism and New Zealand Film Geographies (Bristol: Intellect, 2011).

44 "Page 1 Advertisements Column 6," Press, 15 December 1925, sec. Amusements, Papers Past.

45 See note 4 above.

46 "Buy Australian Goods," Everyone's, 14 June 1925, Adventures of Algy File, Ngā Taonga Sound and Vision.

47 The description of the film as "Australian goods" of course points to another significant aspect of its settler-colonial modernity: namely that Smith himself was Australian. For a critically insightful discussion of cinema's roles in each territory, see Limbrick, Making Settler Cinemas.

Journal of New Zealand Studies NS25 (2017), 40-56 
${ }^{48}$ Edwin S. Porter, The Great Train Robbery, 1903; Tom Gunning, "The Cinema of Attractions: Early Film, Its Spectator, and the Avant-Garde," Wide Angle 8, no. 3\&4 (Fall 1986): 70.

${ }^{49}$ See, for example, "The Dandies" Evening Post, 20 September 1912; "Page 2 Advertisements Column" Evening Post, 23 December 1924; "Page 1 Advertisements Column," Otago Daily Times, 13 September 1922; "Princess Theatre" Otago Daily Times, 29 December 1924, p.2; "The Dandies of 1920," Evening Star, Issue 17405, 15 July 1920: all Papers Past.

${ }^{50}$ In particular, the scene recalls the 1904 Biograph film Personal, which was remade in the same year by Edwin S. Porter and the Edison Company as How a French Nobleman Got a Wife Through the New York Herald Personal Columns (1904). For discussion of the "chase film," see Miriam Hansen, Babel and Babylon: Spectatorship in American Silent Film (Cambridge, MA: Harvard University Press, 1994), 46. For discussion of the community comedies, see Minette Hillyer, "Dominion Screen Types and Local Beauty Spots: New Zealand's Pre-War Community Films," New Zealand Journal of Media Studies 11, no. 2 (2009).

${ }^{51}$ Brannigan, Dancefilm, 36.

${ }^{52}$ Rony, The Third Eye, 102.

${ }^{53}$ Gilles Deleuze, Cinema 1: The Movement Image, trans. Hugh Tomlinson and Barbara Habberjam (London: Athlone, 1986), 4.

${ }^{54}$ Deleuze gives as examples of this phenomenon Fred Astaire's "action-dance" or Chaplin's "actionmime," which responded to their generally urban environments in a way that was peculiarly cinematic. Ibid., 6-7.

${ }^{55}$ Béla Balázs, Béla Balázs: Early Film Theory., ed. Erica Carter, trans. Rodney Livingstone (New York, Oxford: Berghahn Books, 2010), 10.

${ }^{56}$ Carter, in Ibid., xlii.

${ }^{57}$ Ibid., xxiv.

${ }^{58}$ For a comparable conversion of indigenous dance to colonial artifact, see Adria L. Imada, "Hawaiians on Tour: Hula Circuits through the American Empire," American Quarterly 56, no. 1 (March 1, 2004): $111-49$.

${ }^{59}$ Dennis, interview.

${ }^{60}$ Mary Ann Doane, "Dark Continents: Epistemologies of Racial and Sexual Difference in Psychoanalysis and the Cinema," in Femmes Fatales: Feminism, Film Theory, Psychoanalysis (London and New York: Routledge, 1991), 215.

${ }^{61}$ Appadurai, Modernity at Large, 3.

${ }^{62}$ Nicholas Thomas, Colonialism's Culture: Anthropology, Travel, and Government (Princeton, NJ: Princeton University Press, 1994), 3.

${ }^{63}$ Hansen, "The Mass Production of the Senses," 68.

Journal of New Zealand Studies NS25 (2017), 40-56 